\title{
Transformation of Chinese as a Foreign Language Teachers' Relationship with Their Students in the Australian Context
}

\author{
Yu Han ${ }^{1}$, Xiaoyan $\mathrm{Ji}^{1}$, Jinghe $\operatorname{Han}^{2}$ \\ ${ }^{1}$ Zhuhai College of Jilin University, China \\ ${ }^{2}$ Western Sydney University, Australia \\ Correspondence: Yu Han, Zhuhai College of Jilin University, China.
}

Received: June 02, 2019

doi:10.11114/ijce.v2i2.4393
Online Published: July 21, 2019

URL: https://doi.org/10.11114/ijce.v2i2.4393

\begin{abstract}
This study explores the transformation of teacher-student relationship between expatriate Chinese as a Foreign Language (CFL) teachers and their students situating in the Australian educational context. The disparity of tradition between the two educational cultures influences substantially on communication between teachers and students within classroom. To better understand how CFL teachers' background educational culture may impact their interaction with Australian students, focus group discussion data were applied as the data collection method. Findings reveal that at the beginning of their teaching practice CFL teachers' understanding of teacher-student relationship influenced by their background educational culture had major impact on their strategies in teacher-student interaction in class. However, with the progress of teaching and meantime influenced by the Australian local educational culture, their behaviors for dealing with teacher-student relationship in class changed. Basically, their ways of handling teacher-student relationship transformed from a more Eastern guanxi tendency to a more Western rapport tendency. This transformation did not occur automatically and easily; it was achieved by the CFL teachers' struggles and tribulations in the process of interacting with their Australian students. In an era of CFL teacher shortage, it is hoped that this study would shed some light on CFL teacher education.
\end{abstract}

Keywords: Guanxi, rapport, teacher-student relationship, transformation

\section{Introduction}

\subsection{Context of the Study}

Along with the economic boost of China, Chinese as a Foreign Language (CFL) has been taught widely around the globe. Majority of CFL teachers, who teach outside China, are Chinese native speakers (Orton, 2008; Chen, 2015). Thus, their students' cultural background, within which they teach CFL, is different from theirs. Their teacher-student relationship building strategies and approaches with their non-Chinese background students, mainly come from their experience - their teaching beliefs shaped by their cultural background (Han \& Yao, 2013; Czura, 2016; Han \& Han, 2019) and their prior experiences as students (Borg, 2003). This situation causes them struggles fitting into the local educational culture where they teach (Chen, 2015) because their previous experiences do not concern intercultural communication within classrooms as Weinstein, Tomlinson-Clark and Curran (2004) mentioned that one main challenge within intercultural classrooms for beginning teachers and students is potential misunderstanding of the two parties come from two socio-cultural backgrounds.

In Australia, CFL teaching outcomes are considered unsatisfactory mainly because of students' low academic achievement and high dropout rate (Orton, 2008; Chen, 2015; Orton, 2017). The major reason for this is identified as qualified CFL teacher shortage (Orton, 2008; Orton, 2011). When crossing border, CFL teachers encounter crosscultural obstacles interacting with Australian students (Chen, 2015; Han \& Han, 2019) because of a lack of understanding of the students and the Australian educational culture, which in turn impede the progress of Chinese teaching and learning (Orton, 2008) and result in inefficient pedagogy for Australian students' diverse learning needs (Clark \& Gieve, 2006; Orton, 2011). Coming from a culture where teachers enjoy automatic respect from students, the CFL teachers experience challenges and predicaments at the beginning of teacher-student relationship building in the Australian educational context.

This study aims to find out how CFL teachers' cultural background could influence their relationship with their 
Australian students and how they handle the issues they face to accommodate themselves to Australian CFL classes with the progress of teaching. The following section starts with an introduction of the significance of rapport, after which the theoretical concepts based on Eastern and Western divergent understandings of teacher-student relationship are presented. After a presentation of the two research questions, the research method is elicited and findings are presented and discussed.

\subsection{Significance of Teacher-Student Relationship}

The influence of positive and negative teacher-student relationship on learning and teaching has been studied by researchers (e.g.: Wubbels \& Brekelmans, 2005) and a consensus has been reached that positive teacher-student relationship (rapport) plays an important role in the success of both learning and teaching. For students, rapport is related closely to their class participation and learning motivation (Frisby \& Martin, 2010; Ahmad, 2016). Glazier (2016) points out "rapport has a strong, significant, and consistently positive effect" (p. 438) in helping students learn, which is in line with den Brok, Brekelmans and Wubbels' "teacher is one of the elements contributing to the opportunities for pupils to learn" (2004, p. 409). It could reduce anxiety, increase class participation, encourage classroom interaction, create a positive environment and promote students' learning (Frymier \& Houser, 2000; Frisby \& Martin, 2010). Rapport makes students feel "being valued, known, connected, and respected" (Frisby \& Martin 2010, p. 149). It is common that students like a subject because of a teacher (Yang, 2008). It could also lower the number of students' failure in a course (Glazier, 2016). Students, who are in a rapport with their teachers, tend to concentrate better and have positive learning attitude. Rapport is found significant in successful communication, "especially in terms of second language learning" (Ahmad, 2016, p. 13). For teachers, rapport represents more of interpersonal aspect of teaching, which involves the personal level of teacher-student relationship (Ahmad, 2016). Teacher-student rapport is critical in that it not only contributes to the development of personal relationship, but also emphasises teachers' role in understanding students through teaching process. Rapport also improves teachers' well-being (Ahmad, 2016) because an easy-going environment makes their teaching enjoyable and rewarding.

The existing literatures on expatriate CFL teacher-student relationship demonstrate that cultural backgrounds exert tremendous impact on it (e.g.: Han \& Han, 2019; Han, 2019; Chen, 2015; Li \& Jensen, 2013). For example, Li and Jensen (2013) studied CFL teachers' teaching practice in the Denmark context and found that their cultural background impacted their relationship with Danish students. However, there is a lack of study on CFL teacher-student relationship in the Australian context (Han \& Han, 2019). For better understanding of the factors from both the Chinese culture and the Australian culture by which these CFL teachers are influenced, this paper focuses on researching into the teacher-student relationship building practice of a group of CFL teachers who teach in Australia. The following section starts from a comparison between the Eastern and Western educational ideologies, by which they are impacted and shaped.

\section{Theoretical Framework: Eastern and Western Understanding of Teacher-student Relationship: Guanxi and Rapport}

\subsection{The Social Contexts of Guanxi and Rapport}

Guanxi (关系: relationship) refers to "relationships between two parties", including relationships among family members, friends, colleagues and teacher-students (Chen \& Starosta, 1997, p. 5). Chinese culture values guanxi, which is influenced by the Confucian ideology that people are products of guanxi (Huang, 2000). The Chinese guanxi posesses two major unique features: respect and hierarchy (Han \& Han, 2019). Respect indicates unconditional respect. Hierarchy is the fear of authority under the influence of the traditional idea shang zun xia bei (上尊下卑: high status people are superiors and should be respected; whereas low status ones are inferiors and should be humble) (Wong, 2016).

The counterpart of the Chinese concept guanxi is rapport in Western culture. Hall, Roter, Blanch and Frankel defined rapport as "a relationship that was pleasant and engaging, a high degree of liking or positive affect, mutual attention, harmonious relation, easy/smooth communication, and/or symmetry and synchrony in the interaction" (2009, p. 324). This definition incorporates two dimensions: an enjoyable interaction and a personal connection (Gremler \& Gwinner, 2000, cited in Frisby \& Martin, 2010), which both emphasize the emotional connectivity between people, from which we could be informed that in the Western world rapport is more of an emotional connection emphasizing ideological resonance and harmony. In teaching, rapport is defined as harmonious interactions between teachers and students (Bernieri, 1988), which is an overall positive relationship between teachers and students (Wilson, Ryan \& Pugh, 2010; Ryan, Wilson \& Pugh, 2011).

This revelation of social contexts assists our insight into the complexity of impacts by which the CFL teachers' ideology of teacher-student relationship was shaped. In this paper, the influence on their instructional practice comes from two educational cultures: the Chinese educational culture and the Australian educational culture because they situate in both cultures at different times. A list of comparison and contrast of the concepts in Chinese and Western culture regarding the understanding of teacher-student relationship composes the theoretical framework of this paper. 


\subsection{Authoritative vs Egalitarian Teacher-Student Relationship}

The two characteristics of Chinese guanxi - respect and hierarchy, contribute to Chinese teachers' authoritative status. They are the unchallengeable authority in class. Traditional Chinese teacher-student relationship is a unidirectional student-respect-teacher relationship (Song, Kwan, Bian, Tai \& Wu, 2005). This could be traced back to Song Dynasty when Fan $\mathrm{Ye}^{1}$ advocated zun shi zhong dao (尊师重道: respect teachers and value their teaching). In such a social context, it is natural for Chinese students to believe that they need to respect their teachers who are more knowledgeable and experienced. Students are also reminded by their parents that they should respect their teachers (Wong, 2016). Thus, in the Chinese context, students' respect toward teachers is unconditional respect. Hierarchy is another important characteristic in Chinese teacher-student relationship. Teachers possess high social status. Han Yu, one of the most renowned educators in Tang Dynasty, described teachers as those who chuan dao shou ye jie huo (传道授业解惑: show you the way of being human, teach you knowledge and enlighten you while you are confused) (Shi Shuo/On Teachers) (Yin \& Lee, 2012). Students, thus, hold the idea that teachers are in a higher position and should be looked up to (Wong, 2016). Even in Hong Kong, a more Westernised area of China, "traditional Chinese respect for authority permeates the hierarchical teacher-student relationship" (Wong, 2016, p. 251). One aspect needs to be mentioned is that harmonious relationship is cherished and emotional influences amongst people are valued in Chinese culture (Yin \& Lee, 2012) despite the fact that teacher-student relationship is based on respect and hierarchy. In such a context of hierarchy and respect, it is "difficult to equalize the relationship between the teacher and the student" ( $\mathrm{Li} \& \mathrm{Du}, 2013$, p. 89).

In contrast, Western society supports a democratic teacher-student relationship, in which teachers and students are seen as equal counterparts ( $\mathrm{Li} \& \mathrm{Du}, 2013$ ). Western teachers need to work hard to earn respect (Rushton, 2000) and respect is built in teacher-student interactions (Goodman, 2009). In Denmark, for example, teachers endeavor to create less hierarchical teacher-student relationship in class so that students would not be terrified to participate in classroom activities; teachers often restrain the eagerness of positioning themselves as masters or experts; instead, they invite students to challenge them and ask them questions (Zhang \& Jensen, 2013).

\subsection{Collectivism vs Individualism Educational Ideology}

Collectivist cultures value more social relationships and groups, whereas individualistic cultures value individuals (Triandis, McCusker \& Hui, 1990). Influenced by the Confucian culture, Chinese educational culture supports collectivism, which brings conformity (Li \& Jensen, 2013), unquestioning loyalty and pursuit of group goals (Hofstede, 2001). In contrast, Western countries value individualism and independence (Leung, 1998; Hofstede, 2001).

The differences between collectivist culture and individualistic culture is well summarized by Triandis (1993): In collectivist cultures, "in-group harmony is required" (p. 165), "most interaction is between an individual and groups" (p. 166), and relationships are hierarchical. In contrast, in individualistic cultures, confrontation and debate are acceptable, "most interaction is between an individual and one other individual" (p. 166), and relationships are egalitarian.

\subsection{Teacher-centered vs Student-Centered Pedagogy}

In China, teachers are viewed as masters and experts in class because they are the knowledge resource (Li \& $\mathrm{Du}, 2013$ ). Thus, in tradition, the Chinese educational system is teacher-centered, in which teachers guide the class and "focus on the maintenance of order" (Garrett, 2008, p. 35). To enhance students' motivation in learning, educational institutions in China have made efforts to transform the teacher-centered approach to the student-centered approach; however, practically they meet challenges, because "In practice, transforming the relationship between the teacher and the student requires a change of the conception of the teacher-student relationship" (Li \& Du, 2013, p. 81). This transformation could not be easily realized since teacher-centeredness is originated from the broader social context in which teachers' work are highly valued.

In comparison, Western society values students' interest in learning (Gao \& Watkins, 2002, cited in Li \& Du, 2013), in which a student-centered pedagogy is formed and encouraged. This student-centered approach values more of creating a co-constructed learning environment by teachers and students, in which teachers' instructional decisions are based on students' needs and teachers and students respect each other (Garrett, 2008).

\subsection{Large vs Small Teacher-Student Power Distance}

Power distance is "the extent to which the less powerful individuals from institutions expect and accept that power is distributed unequally" (Hofstede, 2001, p. 98). There are large power distance and small power distance cultures. The former accepts the unequal distribution of power, while the latter supports relatively equal distribution of power (Merkin, 2006). The relationship between the teacher-student pair is embedded in such different cultures.

Large power distance is shown in the teacher-student relationship in the Chinese culture, for example, which is reflected from respecting teachers within and outside the classroom by both students and parents as well as teachers' dominate and leading role in class (Hofstede, 1986). The basic societal issue caused by this large power distance is 
"social inequality and the amount of authority of one person over others" (Hofstede \& Bond, 1984, p. 419). Teachers as knowledge authority possess more power over students in the educational context in such culture. Thus, a type of hierarchical relationship is formed between teachers and students (Kirbebæk, Du \& Jensen, 2013; Li \& Du, 2013) and this hierarchy is accepted as a normal part of the society (Zhang, 2005). However, this hierarchy caused by large power distance results in less teacher-student interaction and students' inactive participation in class (Zhang, 2005).

Small power distance is believed to be the social norm of Western societies, for example, Denmark (Kirbebæk, Du \& Jensen, 2013). In small power distance societies, people favor "relatively equal distribution of power in society" (Zhang, 2005, p. 114). Unlike large power distance societies, in which distance is lengthened and hierarchy is encouraged, small power distance societies shorten distance and support egalitarianism (Zhang, 2005).

To shrink the power distance between teachers and students is a prerequisite of a democratic and equal teacher-student relationship ( $\mathrm{Li} \& \mathrm{Du}, 2013$ ). The approaches to do so include, for example, using humor to create enjoyable and relaxed learning environment so that students' willingness of classroom participation increases (Wanzer \& Frymier, 1999) and teachers disclosing themselves and giving personal examples when there is a chance in class to alleviate teacher-student tension and students' anxiety in class (Myers, Zhong \& Guan, 1998).

\section{Methodology}

\subsection{Contexts and Participants}

CFL teaching and learning has been popular in Australia since the last decade. The Australian government implemented several policies to promote CFL teaching and learning, for example Melbourne Declaration on Educational Goals for Young Australians (Department of Education, 2008) and The National Asian Languages and Studies in Australian Schools Strategy (NALSAS, cited in Wang, Moloney \& Li, 2013). Driven by these policies, CFL learners' number increased dramatically (Moloney \& Xu, 2018); however, there was still a lack of qualified CFL teachers. To solve the problem, Chinese native speakers were brought in through cooperation programs such as the Research-Oriented School-Engaged Teacher-researcher Education program (ROSETE).

ROSETE is a multilateral cooperative program among Hanban (汉办: Confucius Institute Headquarters, Beijing, China), the New South Wales Department of Education (Sydney, Australia), Western Sydney University (Sydney, Australia) and the Ningbo Municipal Education Bureau (Ningbo, China). The Ningbo Municipal Education Bureau selects students with their Bachelor's or Master's degree and sends them to Western Sydney University to further their study for pursuing Master's or Doctor's degree in educational research. Meanwhile, they work as CFL teachers in Western Sydney primary and secondary schools. They base their research on their teaching experience. This program has been valued by the Australian local society because it perfectly balances "the relationship between teachers-asknowledge workers and researchers-as-knowledge producers" (NSW Government, 2012 cited in Singh and Han, 2015, p. 166-190). Teaching new students in a new culture, they have to adjust themselves to fit into the new educational environment and integrate prior knowledge with new experience. It is a great challenge for them to engage students with different cultural backgrounds and build a harmonious teacher-student relationship.

The five participants of this study were from ROSETE, three of them are females and two are males. One of the females (Betty) is in her 30s who is one of the doctoral students and who had four years of English teaching experience in a Chinese university before came to Australia. All the other four participants are Master's students who had not worked as full-time teachers but all had some tutoring or part-time teaching experience around three months either in teaching internship before graduation from the previous degree or as tutors in after-class tutorial groups.

\subsection{Data Collection Method}

This study was approved by the Human Research Ethics Committee of Western Sydney University (approval number H11038).

This study employed focus group discussion as the data gathering method. The five expatriate CFL teachers participated the discussion voluntarily and an ethical consent paper was signed by each of them, before which they were notified about their data confidentiality.

A two-hour group discussion in Chinese was conducted, aiming to generate data through "communication between research participants" (Kitzinger, 1995, p. 299). The discussion was unfolded around several open-ended questions designed and initiated by the researchers of this study around how they viewed Chinese background teachers teaching Australian students, and how they developed teacher-student relationship in such a cross-cultural context. In the discussion, they shared their experiences in both China and Australia, exchanged classroom anecdotes, and commented on one another's views. The discussion was sound recorded. 


\subsection{Data Translation, Coding and Analysis}

The collected data were transcribed, translated, coded and categorized by the authors. Before data coding, the transcribed manuscripts were sent back to the participants for checking and confirmation. The four major pairs of data coding themes are shown in the table below:

Table 1. Themes for data coding

\begin{tabular}{l|l}
\hline \multicolumn{2}{l}{ Data Coding Themes } \\
\hline 1 & Authoritative and egalitarian teacher-student relationship \\
\hline 2 & Collectivist and individualistic teacher-student relationship \\
\hline 3 & Teacher-centered and student-centered relationship \\
\hline 4 & Large and small teacher-student power distance \\
\hline
\end{tabular}

Data analysis mainly contributed to answer the following two research questions:

(1) What are the cultural impacts on the CFL teachers' relationship building with their Australian students?

(2) How do they deal with these cultural impacts on their teacher-student relationship building in the Australian context?

By answering these two questions through group discussion, we aim to understand better the CFL teachers' experience of handling teacher-student relationship in a new cultural context and to identify effective coping strategies teaching abroad so that future CFL teachers could learn from them.

\section{Findings}

\subsection{Confusion of Authoritative and Egalitarian Teacher-Student Relationship}

The CFL teachers were trapped in confusion of whether to be authoritative teachers or egalitarian teachers in the Australian educational context. This confusion came from their initial practice of building up teacher-student relationship by ways from both cultures without success.

We formed stereotypes of typical Chinese classes when we were students in China... We expect respect and participation. (Sarah)

At the beginning, I expected Australian students the same as Chinese students who focus on teachers' lectures. However, they were different. When students got naughty, I did not criticise them, rather I reminded them to stop talking by using mild voice. ... If they refused to change their seats as I told them to, I would just tell them to close their mouths instead. I had high expectation for myself before, hoping I could manage my classes well, but unfortunately, it was difficult. (Jack)

If I was a teacher in China, I will be stricter with my students, because in China exam results are very important. In Australia, I put more emphasis on students' engagement. My final goal here is to get my students interested in Chinese. "I do not criticise you [his students] so you do not go too far". ... I adopted detention, but things after that were even worse: I did not know what to do. (Steven)

The CFL teachers' confusion was displayed by their four-step attempts in building teacher-student relationship and their authority in class. First, they confirmed the influence from their background educational culture on their teaching in Australia. They expected students' respect and their automatic class participation. However, data show that what the CFL teachers learned from their previous teachers did not guarantee them authority in Australian classes. Second, in such an unfavorable situation, the CFL teachers switched their methods and they searched for help from the Australian educational culture, by which they were influenced as well. However, adoption of the Australian way of building egalitarian teacher-student relationship by engaging students more in class did not bring them success. Third, to establish authority in the Australian context, they sought for help from local ways learned from Australian classroom teachers: putting students on detention, which did not bring them effectiveness in classroom management, rather, it added more confusion and ended them in bewilderment. Last, failed at gaining authority in their Australian classes, they adjusted their teacher-student relationship strategy to make compromise for peace in class.

Jack's confusion was shown in another statement of his as well:

Chinese students' attitude toward studying and teachers is different from Australian students'. Australian students are naughtier and do not respect class much. ... I learned Ah Q Spirit ${ }^{2}$ here. However, Australian teachers' classroom languages are strict, clear and firm. Students listen to their classroom teachers. (Jack)

Jack contributed his non-success in building up rapport with students and classroom management to Australian students' 
negative attitude toward learning, which according to him was out of his controllable range. Therefore, he adopted Ah Q Spirit, which demonstrated his compromise again. However, he noticed that dealing with the same group of Australian students, their classroom teacher had authority over students, which was shown from their strict and firm languages to manage class and students' obedience. This finding of his added him more confusion.

This finding of the CFL teachers' confusion in teacher-student relationship indicates the CFL teachers' dichotomy of the Chinese and Australian ways of teaching and teacher-student relationship building. They view the Chinese and Australian ways of teacher-student relationship as two different and contradictory systems. This view resulted in their confusion and dilemma in choosing which system to apply. This could be shown from their categorization of the two ways of being effective teachers in the two cultures (Table 2):

Table 2. Words represent for authoritative and egalitarian teacher-student relationship

\begin{tabular}{c|l}
\hline \multicolumn{1}{c|}{ Authoritative } & \multicolumn{1}{|c}{ Egalitarian } \\
\hline $\begin{array}{l}\text { strict, exam, respect, criticise, passive, exam, } \\
\text { homework, detention, punishment }\end{array}$ & $\begin{array}{l}\text { engagement, interest in, willing to, eager to, participation, } \\
\text { equal, friendly, arouse enthusiasm }\end{array}$ \\
\hline
\end{tabular}

In their mind, words in the left column symbolises authoritative status of teachers while in the right column, egalitarian teacher-student relationship. They were confused in the Australian classes in dealing with teacher-student relationship because in their teaching process they tried to shift from one column to the other.

\subsection{Shifting of Teaching Ideology: From Collectivism to Individualism}

Influenced by the Australian educational culture, the CFL teachers learned that the Chinese collectivist method of treating students was not the only way. They found that Australian schools aiming at training students to be independent individuals, which both amazed them and inspired them.

When Australian teachers evaluate students, they do not only focus on academic achievement. Even though a student does not perform well in class, s/he may still be a very good student. Once I saw a teacher marking the characteristics of each student, including their specialties. Australian teachers see their students' individualities. If I have a chance to evaluate students, I may say this student concentrate on what we learn during my lessons. I may pay more attention to their academic achievement because in my former experience good students are those who get high scores. (Sarah)

The CFL teachers, for example Sarah, noticed the difference between the Chinese way and the Australian way of student evaluation: academic achievement and individualities/diversity. Australian teachers welcome diversity, which is contrary to their previous experiences. Profoundly influenced by Chinese educational culture, she regarded score as the sole criteria for student evaluation. However, after teaching in Australian schools, they realized the necessity to value students' diversity, not by their scores but by their characteristics and specialties. Once learned how to evaluate students from more perspectives, they grew in understanding Australian educational culture and they shifted their approaches accordingly.

\subsection{Transformation of Pedagogy: From Teacher-Centered to Student-Centered}

The CFL teachers demonstrated a transformation in pedagogy from a more teacher-centered method influenced by their background educational culture to a more student-centered approach impacted by the Australian educational culture.

I remember when I was a student in China; we flattered our teachers. We showed our respect. We listened to their lessons carefully and responded to their questions cooperatively because we knew this would benefit ourselves. When I became a teacher, I thought it was normal for my students to treat me that way because that was how I treated my teachers. Some [Australian] students do not care about teachers. In their mind, they think they do not necessarily need to do what teachers tell them to do. They do whatever they want. This is the root for contradictions. I could think students are making troubles, while students could think my lessons are boring. If I were going back to China to be a teacher, I would engage students more and will not be a teacher like my former teachers who are teacher-centered and teacher-dominant. (Jack)

Once I wanted to teach students the Chinese Birthday Song. I thought it would be good if there were students whose birthday was around. Therefore, I went to the school office and asked for a name list. I found that day was coincidentally a girl's birthday. Then there was a plan. On my teaching day, I told my students we were going to learn the Birthday Song in Mandarin, and we would learn the song and sing it for a secret person. Then I showed the student's name on the PowerPoint I prepared and we learned the song and sang the song to her. She was a shy girl but was very happy that day. Since then, I found her changed a lot and in a test afterwards, she got all the answers right. (Sarah)

Jack admitted that the Chinese teacher-centered approach was deeply carved into Chinese culture and his mind. 
Knowing to follow teachers' instructions was doing himself a favor when he was a student; he would do anything to make his teachers happy. He thought his Australian students would be the same. However, he realized the situation in Australia was different, which caused conflicts between him and his students and led to his loss of authority in class. After getting some experience in the Australian educational context, Jack made reflection and transformed his ideology of teacher-student relationship from a teacher-centered to a student-centered one. This transformation would impact on his future teaching practice as he pictured his future as a student-centered teacher back in China.

In Sarah's instance, she achieved positive feedback beyond her expectation by implementing student-centered pedagogy. The girl student's switch from a shy girl to a student of excellent achievement in Chinese learning proved her adaptation and effectiveness in application of the student-centered pedagogy. This student-centered pedagogy did not deprive her power as a teacher in Australian classroom, rather, she was granted power through putting students at the center, which, in return, contributed to harmonious teacher-student relationship. Sarah's endeavor to engage students to learning proved Van Tartwijk, den Brok, Veldman, and Wubbels' finding that it is of significance in "building trustful relationships by using and creating opportunities to get to know students and invest time in building relationships" (2009, p. 457).

\subsection{Narrowing Down Power Distance Through Humor and Self-revelation}

In large power distance cultures such as China, teachers tend not to disclose their emotional variation in front of students for maintaining their authoritative image. However, situating in the Australian educational context where teachers and students have relatively small distance power, it was necessary for the CFL teachers to make appropriate adjustment to adapt to the situation. Humor is an effective strategy to narrow down power distance, to relax a class and to attract students' attention. It may also arouse students' curiosity to know more about Chinese language and culture as a consequence. Bell (2007) indicated, "Humor in a second language (L2) can present an intimidating linguistic and cultural challenge for L2 speakers, yet it is a crucial means by which friendships are developed" (199).

When we learn the topic "made in China", I said, "God created the world and everything else is made in China." Students laughed. Then I went on asking them the things they know that were made in China. They were quite into the topic and even showed me examples like their shoes or school uniform tags. (Betty)

Once when we were having class, a cockroach came out. I caught it with a piece of paper trying to put it in the bin, but it suddenly fell off my hand. I shouted "Wo kao" spontaneously. Students were quite interested in the meaning of "Wo kao". I explained it means "Oh my God" and they tried to repeat it. Then with this opportunity, I taught them the nickname of cockroach in China - Xiao Qiang ${ }^{3}$ (literally, Little Strong) and explained the reason why they are called Xiao Qiang. They like the story very much. (Jack)

The CFL teachers learned to shrink power distance through humor for building a better teacher-student relationship. Betty's "God created the world and everything else is made in China" created harmonious classroom atmosphere and made herself more approachable (Glazier, 2016), which contributed to a better teacher-student relationship. Jack's accidental disclosure of his real self by an emergent cockroach alleviated teacher-student tension in class (Myers et al., 1998) and thus, narrowed down the power distance between him and his students, which contributed to better teacherstudent relationship and students' learning interest and opportunity.

\section{Discussion}

Teacher's professional identity is dynamic and transformable along with contexts shift and teacher development (Beauchamp \& Thomas, 2009). When teaching abroad, this dynamic process involves constant reflections, explorations, experiments and problem-solutions (Borg, 2003). The CFL teachers' preexisting educational conceptions on teacherstudent relationship (guanxi), such as teacher-centered pedagogy, were obstacles on their way of building rapport with their Australian students and becoming capable teachers in Australia. These conceptions were gradually identified and reconstructed by themselves in the process of interacting with students in the Australian educational context. Their strategies in building teacher-student relationship, thus, were transformed from a more Chinese guanxi way to a more Australian rapport tendency, which was more coherent with the Australian educational context.

To achieve effective teacher-student communication, the CFL teachers made efforts to balance their use of authority and equality in the Australian educational context. For the CFL teachers who come from a culture where teachers are the authority in class (Wong, 2016; Lewis, Romi, Qui \& Katz, 2005), to balance authority and equality in communication with their Australian students was challenging because their initial classroom behaviors were shaped by their prior experiences in China including their experiences as students (Li \& Jensen, 2013; Borg, 2003). Thus, at the beginning of teaching in an alien educational context, the CFL teachers' conceptions of teaching were still influenced more by their Chinese educational culture background, which could explain why they practiced teacher-centered 
pedagogy, for example, and why they wanted to be the authority in class. Apparently, they experienced struggle in choosing appropriate teaching approach to establish rapport with students between different educational cultures (Li \& Jensen, 2013). The struggle came from their demarcation of and confrontation with the two competing educational cultures in their mind. Kirbebæk, Du and Jensen (2013) indicated that this kind of struggle for the CFL teachers might be avoided if they could eliminate background cultural influence situating in a new cultural context, which the authors consider is unlikely to occur.

The findings of this study are consistent with Moloney and Xu's (2015) finding that CFL teachers struggled in their adaptation to Australian classes transitioning from traditional Chinese pedagogy to Western pedagogy and Van Tartwijk et al. (2009) finding that multicultural classrooms provide additional challenges for teachers. The CFL teachers' initial confusion and struggle in managing teacher-student relationship demonstrated their "low levels of professional knowledge of intercultural pedagogy" (Moloney, 2013, p. 225), which may create barriers on the way of training their students to be functional users of the language they are teaching (McDonald, 2011). However, their transformation of teaching practice indicated opportunities and potentials for their professional development. Their positive smooth accommodation to Australian class was achieved when these CFL teachers tried adjusting their teaching pedagogy so that rapport could be built with students (Han \& Han, 2019; Van Tartwijk et al., 2009). They did make improvement in teacher-student relationship along with the progress of their teaching practice. They learned the importance of viewing students as individuals; they practiced student-centered pedagogy and gained positive feedback from students; they adopted humor as a strategy to shrink power distance and turned them into chances of extensive learning. These alterations of CFL teachers have broken the stereotype of the traditional Chinese teacher image: serious, conservative and dogmatic. Their thinking was broadened through cutting some edges off the stereotype from their background culture. These successful experiences come from their conscious and voluntary adjustment in fitting into the new educational context, which, in return, granted them success in dealing with teacher-student relationship in Australian classes, which is in line with the findings of Han and Han (2019) and Singh and Han (2015) that teaching in the Australian educational context, the CFL teachers developed the consciousness of the divergence between Chinese and Australian educational culture and they made certain adjustment and transformation to adapt themselves to the new cultural context.

The disclosure and research of the transformation of CFL teachers' ideas and practice of teacher-student relationship in the Australian context may inform and encourage CFL teacher educators to consider and involve this perspective into CFL teacher education programs so that they could provide appropriate support for future CFL teachers' quick and smooth transition to be qualified language teachers in Australia (Han \& Han, 2019). Hopefully, "through continual differentiation and surpassing" with the in-advance and in-time assistance from teacher educators, future CFL teachers could achieve self-promotion and create themselves an inventive future (Jullien, 2014, p. 12) in the Australian context. The findings of this study also indicate the urgency of future research on how teachers with different cultural and educational backgrounds could grow to be effective teachers in new cross-cultural educational contexts.

\section{Conclusion}

This study investigated expatriate CFL teachers' perceptions and practice of building teacher-student relationship in the Australian educational context. Teaching outside their familiar Chinese educational context, they underwent a difficult and complex process of modification and transformation in belief and practice in teacher-student relationship establishment in the Australian context. They eventually mastered the Australian approaches of managing classes and dealing with teacher-student relationship by conscious efforts in teaching approaches transformation. However, due to the small scale of data and its single collection method, not all potential issues and aspects from CFL teachers could be covered. Considering the enormous number of the overseas expatriate CFL teacher cohort, future researches in the field are suggested to enroll more subjects and incorporate wider data source.

\section{Acknowledgements}

The authors appreciate the valuable feedback from the reviewers. The authors acknowledge the support from the participants from ROSETE.

\section{Notes}

Note 1. Fan Ye: Historian and litterateur of Song Dynasty, China.

Note 2. Ah Q Spirit: The spirit of compromising and self-consolation in front of hardships, unachievable goals or defeats. Ah Q is the main character of the famous Chinese writer Xun Lu's novel The True Story of Ah Q in which he is a backward peasant who interprets his failures as moral victories, since then this kind of attitude toward life is named Ah Q Spirit.

Note 3. Xiao Qiang: Nickname of cockroaches in China. They are so-called because they are small-sized yet they are dinosaur-aged. If they are not strong enough, it is not possible for them to live for millions of years. 


\section{References}

Ahmad, N. (2016). Vision and Wisdom for an Effective Teaching of English as a Foreign Language with Reference to the Students of University of Bisha, Saudi Arabia. Bangladesh Research Foundation Journal, 5(1), 1-19. https://www.researchfoundbd.org/images/Vol.5-No.1-2016.pdf\#page=14

Beauchamp, C., \& Thomas, L. (2009). Understanding teacher identity: An overview of issues in the literature and implications for teacher education. Cambridge Journal of Education, 39(2), 175-189. https://doi.org/10.1080/03057640902902252

Bell, N. D. (2007). Safe territory? The humorous narratives of bilingual women. Research on Language and Social Interaction, 40(2-3), 199-225. https://doi.org/10.1080/08351810701354656

Bernieri, F. J. (1988). Coordinated movement and rapport in teacher student interaction. Journal of Nonverbal Behavior, 12(2), 120-138. https://doi.org/10.1007/BF00986930

Borg, S. (2003). Teacher cognition in language teaching: A review of research on what language teachers think, know, believe, and do. Language Teaching, 36(2), 81-109. https://doi.org/10.1017/S0261444803001903

Chen, G. M., \& Starosta, W. J. (1997). Chinese conflict management and resolution: Overview and implications. Intercultural Communication Studies, 7(1), 1-16.

https://digitalcommons.uri.edu/cgi/viewcontent.cgi?article=1015\&context=com_facpubs

Chen, Z. (2015). Challenges of teaching Chinese in Australian schools: Lesson from beginning teacher-researchers. Journal of Language Teaching and Research, 6(5), 933-942. https://doi.org/10.17507/jltr.0605.04

Clark, R., \& Gieve, S. N. (2006). On the discursive construction of 'the Chinese learner'. Language, Culture and Curriculum, 19(1), 54-73. https://doi.org/10.1080/07908310608668754

Czura, A. (2016). Major field of study and student teachers' views on intercultural communicative competence. Language and Intercultural Communication, 16(1), 83-98. https://doi.org/10.1080/14708477.2015.1113753

Den Brok, P., Brekelmans, M., \& Wubbels, T. (2004). Interpersonal teacher behavior and student outcomes. School Effectiveness and School Improvement, 15(3-4), 407-442. https://doi.org/10.1080/09243450512331383262

Frisby, B. N., \& Martin, M. M. (2010). Instructor-student and student-student rapport in the classroom. Communication Education, 59(2), 146-164. https://doi.org/10.1080/03634520903564362

Frymier, A. B., \& Houser, M. L. (2000). The teacher-student relationship as an interpersonal relationship. Communication Education, 49(3), 207-219. https://doi.org/10.1080/03634520009379209

Garrett, T. (2008). Student-centered and teacher-centered classroom management: A case study of three elementary teachers. Journal of Classroom Interaction, 43(1), 34-47. https://files.eric.ed.gov/fulltext/EJ829018.pdf

Glazier, R. A. (2016). Building Rapport to Improve Retention and Success in Online Classes. Journal of Political Science Education, 12(4), 437-456. https://doi.org/10.1080/15512169.2016.1155994

Goodman, J. F. (2009). Respect-due and respect-earned: negotiating student-teacher relationships. Ethics and Education, 4(1), 3-17. https://doi.org/10.1080/17449640902781356

Hall, J. A., Roter, D. L., Blanch, D. C., \& Frankel, R. M. (2009). Observer-rated rapport in interactions between medical students and standardized patients. Patient Education and Counseling, 76(3), 323-327. https://doi.org/10.1016/j.pec.2009.05.009

Han, J., \& Han, Y. (2019). Cultural Concepts as Powerful Theoretical Tools: Chinese Teachers' Perceptions of Their Relationship with Students in a Cross-Cultural Context. International Journal for Scholarship of Teaching and Learning 13(1), 8. https://doi.org/10.20429/ijsotl.2019.130108

Han, J., \& Yao, J. (2013). A Case Study of Bilingual Student-Teachers' Classroom English: Applying the Education-Linguistic Model. Australian Journal of Teacher Education 38(2), 118-131. https://files.eric.ed.gov/fulltext/EJ1012929.pdf

Han, Y. (2019). Linguistic and Cultural Impacts on English Medium Instruction: Chinese Teacher-Researchers' Cases (Unpublished doctoral dissertation). Western Sydney University, Sydney, Australia.

Hofstede, G. (1986). Cultural differences in teaching and learning. International Journal of Intercultural Relations, 10, 301-320. https://doi.org/10.1016/0147-1767(86)90015-5

Hofstede, G. (2001). Culture's consequences: Comparing values, behaviors, institutions, and organizations across nations (2nd ed.). Thousand Oaks, CA: Sage Publications. 
Hofstede, G., \& Bond, M. H. (1984). Hofstede's culture dimensions: An independent validation using Rokeach's value survey. Journal of Cross-cultural Psychology, 15(4), 417-433. https://doi.org/10.1177/0022002184015004003

Huang, Y. H. (2000). The personal influence model and Gao Guanxi in Taiwan Chinese public relations. Public Relations Review, 26(2), 219-236. https://doi.org/10.1016/S0363-8111(00)00042-4

Jullien, F. (2014). On the Universal: The Uniform, the Common and Dialogue between Cultures. (Michael Richardson and Krysztof Fijalkowski Trans.). Cambridge: Polity.

Kirbebæk, M. J., Du, X., \& Jensen, A. A. (2013). The Power of Context in Teaching and Learning Culture. In M. J. Kirbebæk, X. Du \& A. A. Jensen (Eds.). Teaching and learning culture: Negotiating the context (pp. 1-11). Rotterdam: Sense Publishers. https://doi.org/10.1007/978-94-6209-440-6

Kitzinger, J. (1995). Qualitative research. Introducing focus groups. BMJ: British Medical Journal, 311(7000), 299-302. https://doi.org/10.1136/bmj.311.7000.299

Leung, F. (1998). The implications of Confucianism for education today. Journal of Thought, 33, 25-36. https://www.jstor.org/stable/pdf/42590239.pdf?refreqid=excelsior\%3A2a767973c44e30be8520d3394d553eec

Lewis, R., Romi, S., Qui, X., \& Katz, Y. J. (2005). Teachers' classroom discipline and student misbehavior in Australia, China and Israel. Teaching and Teacher Education, 21(6), 729-741. https://doi.org/10.1016/j.tate.2005.05.008

Li, H., \& Du, X. Y. (2013). Confronting cultural challenges when reconstructing the teacher-student relationship in a Chinese context. In M. J. Kirbebæk, X. Du \& A. A. Jensen (Eds.). Teaching and learning culture: Negotiating the context (pp. 79-94). Rotterdam: Sense Publishers. https://doi.org/10.1007/978-94-6209-440-6_6

Li, W., \& Jensen, A. A. (2013). Cultural Influences on Chinese Language Teachers' Perceptions and Beliefs in A Danish Context. In M. J. Kirbebæk, X. Du \& A. A. Jensen (Eds.). Teaching and learning culture: Negotiating the context (pp. 95-112). Rotterdam: Sense Publishers. https://doi.org/10.1007/978-94-6209-440-6_7

McDonald, E. (2011). Learning Chinese, Turning Chinese: Challenges to Becoming Sinophone in a Globalised World. London: Routledge.

Melbourne Declaration on Educational Goals for Young Australians. (2008). Government of Western Australia, Department of Education. http://www.artsedge.dca.wa.gov.au/australian-curriculum/Pages/OV-The-MelbourneDeclaration.aspx

Merkin, R. S. (2006). Power distance and facework strategies. Journal of intercultural communication research, 35(2), 139-160. https://doi.org/10.1080/17475750600909303

Moloney, R. (2013). The role of teacher communication in online collaborative language learning between a Chinese and an Australian school: A cautionary tale. Language and Intercultural Communication, 13(4), 400-415. https://doi.org/10.1080/14708477.2013.776068

Moloney, R., \& Xu, H. (2015). Transitioning beliefs in teachers of Chinese as a foreign language: An Australian case study. Cogent Education, 2(1), 1024960. https://doi.org/10.1080/2331186X.2015.1024960

Moloney, R., \& Xu, H. L. (2018). Teaching and Learning Chinese in Schools: Case Studies in Quality Language Education. Palgrave Pivot, Springer.

Myers, S. A., Zhong, M., \& Guan, S. (1998). Instructor immediacy in the Chinese college classroom. Communication Studies, 49(3), 240-254. https://doi.org/10.1080/10510979809368534

Orton, J. (2008). Chinese language education in Australian schools. Melbourne: The University of Melbourne.

Orton, J. (2011). Educating Chinese language teachers-Some fundamentals. In L. Tsung \& K. Cruickshank (Eds.) Teaching and Learning Chinese in Global Contexts: CFL Worldwide: 151-164.

Orton, J. (2017). Changes in the Chinese landscape: New paths for Chinese language in Australian schools. Babel, 5l(3), 6-13. https://search.informit.com.au/fullText;dn=878649150221480;res=IELHSS

Rushton, S. P. (2000). Student teacher efficacy in inner-city schools. The Urban Review, 32(4), 365-383. https://doi.org/10.1023/A:1026459809392

Ryan, R. G., Wilson, J. H., \& Pugh, J. L. (2011). Psychometric characteristics of the professor-student rapport scale. Teaching of Psychology, 38(3), 135-141. https://doi.org/10.1177/0098628311411894

Singh, M., \& Han, J. (2015). Making Chinese learnable: Strategies for the Retention of language learners. In F. Dervin (Ed.). Chinese Educational Migration and Student-Teacher Mobilities - Experiencing Otherness. London: Palgrave. 166-190. 
Song, G., Kwan, C., Bian, Z., Tai, B., \& Wu, Q. (2005). Perspectives: Exploratory thoughts concerning educational reform with problem-based learning in China. Teaching and Learning in Medicine, 17, 382-384. https://doi.org/10.1207/s15328015tlm1704_12

Triandis, H. C. (1993). Collectivism and individualism as cultural syndromes. Cross-cultural research, 27(3-4), 155180. https://doi.org/10.1177/106939719302700301

Triandis, H. C., McCusker, C., \& Hui, C. H. (1990). Multimethod probes of individualism and collectivism. Journal of Personality and Social Psychology, 59(5), 1006-1020. https://doi.org/10.1037/0022-3514.59.5.1006

Van Tartwijk, J., den Brok, P., Veldman, I., \& Wubbels, T. (2009). Teachers' practical knowledge about classroom management in multicultural classrooms. Teaching and teacher education, 25(3), 453-460. https://doi.org/10.1016/j.tate.2008.09.005

Wang, D., Moloney, R., \& Li, Z. (2013). Towards internationalising the curriculum: A case study of Chinese language teacher education programs in China and Australia. Australian Journal of Teacher Education, 38(9), 116-135. https://doi.org/10.14221/ajte.2013v38n9.8

Wanzer, M. B., \& Frymier, A. B. (1999). The relationship between student perceptions of instructor humor and students' reports of learning. Communication Education, 48(1), 48-62. https://doi.org/10.1080/03634529909379152

Weinstein, C. S., Tomlinson-Clarke, S., \& Curran, M. (2004). Toward a conception of culturally responsive classroom management. Journal of Teacher Education, 55(1), 25-38. https://doi.org/10.1177/0022487103259812

Wilson, J. H., Ryan, R. G., \& Pugh, J. L. (2010). Professor-student rapport scale predicts student outcomes. Teaching of Psychology, 37(4), 246-251. https://doi.org/10.1080/00986283.2010.510976

Wong, M. Y. (2016). Teacher-student power relations as a reflection of multileveled intertwined interactions. British Journal of Sociology of Education, 37(2), 248-267. https://doi.org/10.1080/01425692.2014.916600

Wubbels, T., \& Brekelmans, M. (2005). Two decades of research on teacher-student relationships in class. International Journal of Educational Research, 43(1-2), 6-24. https://doi.org/10.1016/j.ijer.2006.03.003

Yang, Y. (2008). The importance of the teacher for developing interest in learning English by Chinese students. International Education Studies, 1(1), 95-100. https://doi.org/10.5539/ies.v1n1p95

Yin, H. B., \& Lee, J. C. K. (2012). Be passionate, but be rational as well: Emotional rules for Chinese teachers' work. Teaching and Teacher Education, 28(1), 56-65. https://doi.org/10.1016/j.tate.2011.08.005

Zhang, C., \& Jensen, A. A. (2013). Professional Identity Construction of Non-Native Chinese Language Teachers. In M. J. Kirbebæk, X. Du \& A. A. Jensen (Eds.). Teaching and learning culture: Negotiating the context (pp. 113-128). Rotterdam: Sense Publishers. https://doi.org/10.1007/978-94-6209-440-6_8

Zhang, Q. (2005). Immediacy, humor, power distance, and classroom communication apprehension in Chinese college classrooms. Communication Quarterly, 53(1), 109-124. https://doi.org/10.1080/01463370500056150

\section{Copyrights}

Copyright for this article is retained by the author(s), with first publication rights granted to the journal.

This is an open-access article distributed under the terms and conditions of the Creative Commons Attribution license which permits unrestricted use, distribution, and reproduction in any medium, provided the original work is properly cited. 